\title{
Food-based nutrition interventions at community level
}

\author{
Cecilio Morón* \\ FAO Regional Office for Latin America and the Caribbean, Santiago, Chile
}

\begin{abstract}
The Food and Agriculture Organization of the United Nations promotes nutrition interventions considering food as the basis for action, given the strategic role of food and the agricultural sector to improve food security for the community; thus, a large number of people, especially the poor, who participate directly or indirectly in agricultural activities are able to obtain benefits from its multifunctional character. Food-based nutrition interventions have the purpose of improving food production and availability, processing and conservation, supply and commercialization, as well as access and food consumption. The basis of this focus is community and local government participation in the planning, execution, supervision and evaluation of specific interventions. Food-based nutrition interventions include the development of community gardens and farms in urban and rural areas; hydroponic gardens and other related initiatives in urban and periurban agriculture; as well as the promotion of traditional crops with nutritional value and the development of small agro-industries. Food-based nutrition interventions can be implemented to improve the food supply in street and itinerant markets, town squares and rural markets, and street food sales. In all food-based interventions, food safety and quality control must be taken into consideration throughout the food chain. The interventions on nutrition education increase the family's capacity to improve access to and consumption of food. Food-based dietary guidelines and nutrition education in schools are highlighted, as well as the utilization of school gardens.
\end{abstract}

\section{Food-based interventions}

In the Plan of Action of the Food World Summit held in Rome in 1996, governments committed themselves to reduce by half the number of undernourished people before the year 2015, considering 1996 figures (from 800 to 400 million). This goal will not be met if household food security is not taken into account.

One can say that households are food secure when all family members have access to food during the whole year, whether produced or bought, in quantity, variety, safety and cultural acceptability necessary to maintain an active and healthy life, and if they are not subject to excessive risks of losing such access.

In this sense, the FAO promotes the development of plans and programmes at community and family level to increase and improve food production and availability, its processing, conservation, supply and commercialization, and also access to food and food consumption, by promoting food-based nutrition interventions (Food and Agriculture Organization, 1995, 2000).

These interventions are based on the strategic role of food and the agricultural sector in achieving good nutrition and improving food security within the community, at both urban and rural levels, given the number of people, especially the poor, who participate directly or indirectly in agricultural activities and obtain the many benefits of its multifunctional character. The basis of this view is the participation of the community and the local government in the planning, execution, supervision and evaluation of the interventions (Food and Agriculture Organization, 2001).

\section{Food production and conservation}

Within food-based nutrition interventions, family and community gardens and farms - conceived as food production systems which contribute to improve food security of rural and urban households - are highlighted. These increase the supply and consumption of complementary foods such as roots, tubers, legumes, fruits and vegetables, products of animal origin, medicinal plants, spices and others, during the whole year round, resulting in food reserves which can be stored and processed and any surplus sold, thus contributing to the household economy. These initiatives could be the responsibility of the whole family group or of the women, in which case one can have a greater certainty of the use of the benefits obtained to improve the household food security (Food and Agriculture Organization, 1995, 2000).

The hydroponic gardens constitute an alternative when there is not enough available land. It is a low-cost technology, easy to learn, needs little drinking water or rain, and allows family training, especially for women, in the production and consumption of fresh and safe vegetables. Moreover, it promotes self-employment, the development of micro enterprises and the use of the scarce resources of the poor urban and periurban population (Food and Agriculture Organization/United Nations Development Programme, 2003).

One must mention the importance of the production and consumption of traditional under-exploited crops with nutritional value which have been abandoned in favour commercial crops. For example, in the Andean region these constitute an ample group of species, such as grains: quinoa (Chenopodium quinoa), kaniwa (Chenopodium pallidicaule), kiwicha (Amarantus caudatus) and tarwi (Lupinus mutabilis); tubers: oca (Oxalis tuberosa), ulluco (Ullucus tuberosus) and mashua (Tropaeolum tuberosum); roots: arracacha (Arracacia xanthorriza); and fruits: tamarillo (Cyphomandra betacea) (Food and Agriculture Organization, 1997). 
From the nutritional point of view, the under-exploited crops increase the availability of energy and nutrients and provide a balanced diet composition, improving food security in low-income rural and urban households. Moreover, these crops can be cultivated in small family farms with minimum costs of water and fertilizers, in land not appropriate for other crops. Furthermore, small producers and women obtain economic benefits from these income-generating activities.

Initiatives in connection with the urban and periurban population are being implemented to respond to the growing demand for food resulting from the intensive urbanization, poverty and unemployment increase in the cities. These activities are carried out in households and communities, using traditional or innovative systems to improve the availability of and access to fresh food, as well as to generate income and employment.

The development of small rural agro-industries plays an important role as a link between the agricultural sector and the market. These agro-industries improve food production and food trade, generating aggregate value to agricultural products. Also, it contributes to modernizing the sector and improving competitiveness by promoting entrepreneurial focus and exchange of experiences, strengthening the institutional local capacity. Moreover, it permits the development of strategic alliances between small producers and agro-industries, supporting technology transfer and innovative methodologies. Additionally, employment and income generation increase, encouraging women's participation; it facilitates improved supply in urban areas and an adequate management of natural resources.

\section{Food supply and commercialization}

The channels of food supply are extremely important to improve the availability of and access to foods on the part of the community, to facilitate the commercialization by the small producers and the rural agro-industry. Several related interventions can be made with street and itinerant markets, town squares and rural markets as well as food street vendors.

The function of the informal trade sector in urban areas of low income is a significant aspect to be considered in the food supply chain and generating income for poor families. This requires a positive attitude by municipal authorities and special programmes oriented to facilitate the commercialization of food production originating in these sectors.

Food safety and quality control throughout the food chain must be taken into account in all of the food-based interventions. In this regard, it is necessary to strengthen both the control systems at municipal level and the training of producers and food handlers, as well as address consumer education.

\section{Food access and consumption}

The objective of the intervention on food and nutrition education is to increase the capacity of households to take advantage of existing resources to improve their access to and consumption of a variety of safe and quality food in order to guarantee nutritional well-being.

In order to plan an intervention on food and nutrition education, it is necessary to identify nutritional problems, their causes and the affected population; perform an educational diagnosis to analyse the elements which influence the conducts and practices wished to be modified; formulate the objectives in a clear, precise, measurable way and in a specific period of time; select the contents, learning experiences, educational messages and media; and, finally, to elaborate the evaluation system.

The food-based dietary guidelines constitute a strategy to comply with the nutritional goals of the population in support of the food and nutrition policies of the countries and public education in general. These guidelines are comprehensible messages that promote the benefits of healthy nutrition habits for all the population in order to improve the epidemiological profile. In its participative and multi-sector preparation, the nutrition situation, social, cultural, economic, environment and agricultural factors related to an adequate availability and use of food are considered.

School children are part of a priority group for nutrition education, in view of the fact that schools and their programmes represent an ideal opportunity to perform joint and ample nutritional activities with the participation of parents and the community. School education allows the orientation of school children to determine healthy diets and life-styles throughout the life cycle, reinforcing their knowledge during the school education process (Food and Agriculture Organization/Ministerio de Educación/Institutio Nutrición y Tecnología de Alimentos, 2003).

Nutrition education in rural and urban schools is more effective if means of support are available associated to practical activities related to food and nutrition. In this sense, the implementation of school gardens is a tool used as a science laboratory to develop knowledge, experience and practical activities on agriculture, food and nutrition, commercialisation, environmental issues, science and life skills (Food and Agriculture Organization, 2001).

\section{Technical assistance of FAO}

The FAO provides technical assistance to member countries and their institutions at all levels to undertake, execute, supervise and evaluate community food-based programmes, with a participative focus and centred in the community to improve food safety and nutrition in households. This experience is being incorporated in various initiatives, mainly in the Special Programme for Food Security implemented in low-income countries with a food deficit.

This technical assistance can be addressed to create and enrich the capacity of national and local institutions with the view to provide efficient education and communication on food towards the population in general, communities, vulnerable groups and schools, as well as to those responsible for taking decisions.

Furthermore, the FAO prepares and makes known a wide variety of published and electronic material on education and training for nutrition professionals, promoters and teachers, with the objective of contributing to update food and nutrition knowledge and to provide methodologies to allow the promotion of healthy habits of food consumers and to modify attitudes and food practices for improving the nutrition situation of the population.

\section{References}

Food and Agriculture Organization (1995) Manejo de proyectos de alimentación y nutrición en comunidades. Guía didáctica. Roma: FAO; available at http://www.rlc.fao.org/prior/segalim/acclaim/ manejo/faodef1.html 
Food and Agriculture Organization (1996) Guía metodológica de comunicación social en nutrición. Roma: FAO; available at http://www.fao.org/DOCREP/003/X6957S/X6957S00.HTM

Food and Agriculture Organization (1997) Cultivos andinos subexplotados y su aporte a la alimentación. Santiago de Chile: Oficina Regional de la FAO para América Latina y el Caribe; available at http://www.rlc.fao.org/prior/segalim/prodalim/prodveg/cdrom/ contenido/libro10/home10.htm

Food and Agriculture Organization (2000) Mejorando la nutrición a través de huertos y granjas familiares. Manual de capacitación para trabajadores de campo en América Latina y el Caribe. Roma: FAO; available at http://www.fao.org/DOCREP/V5290S/V5290S00.HTM

Food and Agriculture Organization (2001) Guía para la gestión municipal de programas de seguridad alimentaria y nutrición.
Santiago de Chile: Oficina Regional de la FAO para América Latina y el Caribe; available at http://www.rlc.fao.org/prior/ segalim/accalim/guiamuni/

Food and Agriculture Organization/Ministerio de Educación/Institutio Nutrición y Tecnología de Alimentos (2003) Educación en alimentación y nutrición para la enseñanza básica. Proyecto de la FAO TCP/CHI/0065. Santiago de Chile: Oficina Regional de la FAO para América Latina y el Caribe; available at http://www.rlc.fao. org/prior/segalim/accalim/educa.htm

Food and Agriculture Organization/United Nations Development Programme (2003) La huerta hidropónica popular. Santiago de Chile: Oficina Regional de la FAO para América Latina y el Caribe; available at http://www.rlc.fao.org/prior/segalim/ prodalim/prodveg/10046.pdf 